The positive significant effect of these treatments was observed mainly in single pregnant ewes; this observation was correlated with a significant increase of milk yields during machine milking when I $7-\beta$ ostradiol was injected to sheep selected for their low plasma ostrogen levels during pregnancy. Hormonal treatments at the end of pregnancy, increasing plasma levels of prolactin, thyroxin and corticoids, were without effect on milk yiclds during machine milking for 28 days.

One single injection of cestradiol benzoate $(15 \mathrm{mg})$ on day $\mathrm{I}_{44}$ of pregnancy produced a significant increase of the secretory activity of the mammary tissue, however, the development of the mammary gland was unchanged. This treatment did not modify the milk composition and dicl not seem to affect the subsequent fertility of treated ewes as compared with controls.

\title{
Maternal behaviour in sheep : mechanisms of mother-young recognition
}

\author{
P. POINDRON $\left({ }^{*}\right)$ and J. P. SIGNORET \\ Station de Physiologie de la Reproduction, \\ Centre de Recherches de Tours, I.N.R.A., \\ Nonsilly 37380 Monnaie \\ (*) Adresse actuclle : \\ Dept. of Animal Science. The University of Westem Anstralia, \\ Nedlands, WA 6009 (Australie)
}

The inadapted reactions of the ewe can lead to difficulties in the practice of slieep husbandry: refusal of lambs, difficulties in fostering as in adaptation to artificial feeding. The study of maternal behaviour can help in solving these problems. The results presented here only deal with the mutual recognition of lamb and ewe.

Some individual recognition is accomplished at a distance by bleats; however, the success of a suckling attempt at a short distance depends on ewe identification of the lamb by olfaction. Ewe anosmia eliminates lamb discrimination. Such females allow any young to suckle, the behavioural sequence lcading to suckling being disorganized.

This indicates that the maternal bond is established by olfactory cues during a critical period postpartum; the role of other sensory information develops later through the learning process.

4) EConomics

\section{Working time in sheep farming}

\author{
J. BASSEZ, M. GRILLOT, J. GUILLET $(*)$, \\ R. GUGGER and J. M. MANNO (**)
}

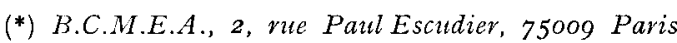

(**) I.T.O.V.I.C., I49, vue de Bercy, 75579 Paris Cedex 12

While references have already been published, systematic study of the working time for different activities in sheep farming systems was only completed in I976. The B.C.M.E.A. and the I.T.O.V.I.C. tape record oral descriptions of the activities concerned as they occur, so that 